(2) Open Access Full Text Article

REVIEW

\title{
A systematic review of sex differences in the placebo and the nocebo effect
}

\author{
Sara MVambheim' \\ Magne Arve Flaten ${ }^{2}$ \\ 'Department of Psychology, UiT, \\ The Arctic University of Norway, \\ Tromsø, ${ }^{2}$ Department of Psychology, \\ Norwegian University of Science \\ and Technology (NTNU), Trondheim, \\ Norway
}

This article was published in the following Dove Press journal: Journal of Pain Research

31 July 2017

Number of times this article has been viewed

Objectives: The present review investigated whether there are systematic sex differences in the placebo and the nocebo effect.

Methods: A literature search was conducted in multiple electronic databases. Studies were included if the study compared a group or condition where a placebo was administered to a natural history group or similar cohort.

Results: Eighteen studies were identified - 12 on placebo effects and 6 on nocebo effects. Chisquare tests revealed that 1) males responded more strongly to placebo treatment, and females responded more strongly to nocebo treatment, and 2) males responded with larger placebo effects induced by verbal information, and females responded with larger nocebo effects induced by conditioning procedures.

Conclusion: This review indicates that there are sex differences in the placebo and nocebo effects, probably caused by sex differences in stress, anxiety, and the endogenous opioid system. Keywords: placebo response, nocebo response, placebo analgesia, nocebo hyperalgesia, sex differences

\section{Introduction}

The placebo effect is a psychological and/or physiological response that follows administration of inert substances or treatments. ${ }^{1}$ For example, an inactive medication administered together with information that it is an analgesic medication has been found to decrease pain and pain-related physiological reactions. ${ }^{2}$ The nocebo effect is defined as increased pain or other symptoms after administration of an inactive treatment purported to increase pain or unpleasant symptoms. ${ }^{3}$

Placebo and nocebo effects have mostly been studied in the field of pain, and sex differences in placebo analgesia ${ }^{4,5}$ and nocebo hyperalgesia ${ }^{3,6}$ have been reported repeatedly. There are sex differences in pain, with males often reporting lower pain to a standard stimulus. ${ }^{7}$ Furthermore, males often have a higher pain threshold ${ }^{8}$ and tolerance than females, ${ }^{9}$ and several pain conditions and pain-related symptoms are more frequent among females ${ }^{10,11}$ - for example, musculoskeletal pain ${ }^{12}$ and fibromyalgia. ${ }^{13}$ Thus, because there are sex differences in experimental and clinical pain, we hypothesize that sex differences exist also in placebo and nocebo responses.

Sex differences in placebo and nocebo responses could be due to sex differences in the underlying psychological or physiological processes mediating placebo and nocebo effects. Placebo analgesia is partly due to activation of a descending painmodulatory system that involves endogenous opioid activation, ${ }^{14}$ and nocebo hyperalgesia is partly mediated through activation of endogenous pronociceptive systems 
involving cholecystokinin $(\mathrm{CCK})^{15,16}$ and HPA hyperactivity. ${ }^{17} \mathrm{CCK}$ has an inhibitory effect on placebo analgesia and an excitatory effect on nocebo hyperalgesia. ${ }^{16}$ Therefore, any sex differences in placebo and nocebo responses may reflect sex differences in these systems.

Endogenous pain modulation obtained by diffuse noxious inhibitory controls (DNICs) - where pain to one stimulus is reduced by application of a second painful stimulus - has been found to reduce pain more in males than in females. ${ }^{18}$ Thus, data suggest that activation of endogenous pain modulation reduces pain more in males than in females, which is consistent with stronger placebo analgesic responses in males compared to females. Stress-induced analgesia (SIA) is also mediated by activation of the descending inhibitory pain pathway, and SIA may take place during or following exposure to stress- or fear-inducing situations. ${ }^{19}$ Males exhibit stronger SIA than females, ${ }^{20}$ and animal studies have shown that SIA may be partially reversed by opioid blockade in males, but not in females. ${ }^{21}$

Aslaksen et al reported that placebos reduced stress more in males than in females, and, when controlling for the effect of stress, the sex differences in placebo analgesia disappeared. ${ }^{4}$ Thus, sex differences in placebo analgesia may be explained by sex differences in stress levels. Potential explanations are that there are sex differences in the pain modulatory system involving endogenous opioids and CCK as well as sex differences in stress responses.

Sex differences in placebo and nocebo responding have also been found in domains other than pain, such as in cognitive performance, ${ }^{22}$ dopaminergic function, ${ }^{23}$ nausea, ${ }^{24}$ and mental distress. ${ }^{25}$ Thus, the observed sex differences in placebo and nocebo responding could also be due to sex differences in information processing. Klosterhalfen et al investigated differences in nocebo responding due to the induction method. ${ }^{24}$ The results revealed that females responded with larger nocebo responses than males when a conditioning procedure was used, whereas males responded with larger nocebo responses than females when a verbal procedure was used. All types of placebo and nocebo effects are mediated through the same psychological processes, namely through expectancies and/or via conditioning procedures. Therefore, the present study investigated whether there are sex differences in the placebo and the nocebo effect, and whether sex differences in the placebo and the nocebo effect are due to the induction method.

The present review hypothesized that 1) placebo responses would be stronger or more frequently observed in males than in females, 2) nocebo responses would be stronger or more frequently observed in females than in males, 3 ) verbally induced placebo responses would be more frequently observed in males than in females, and 4) conditioned nocebo responses would be more frequently observed in females than in males.

\section{Methods \\ Search procedure}

Searches in the Medline, PsycINFO, Embase and ISI databases (Web of Science) were conducted until July 29, 2016. "Sex" refers to biological differences between males and females. "Gender," on the other hand, refers to socially created differences between males and females. However, the terms have not been used consistently across studies, and both terms were included in the searches, although sex differences are the focus of this review. Two searches that included Boolean search terms were conducted in each of the chosen databases. One search was conducted for the placebo and nocebo effects, and one search was conducted for placebo analgesia and nocebo hyperalgesia (Table 1). A review protocol does not exist, but a list of the excluded articles can be forwarded by contacting the corresponding author (SMV).

\section{Data extraction}

One author (SMV) extracted data from the included studies. The other author (MAF) checked these data. The search resulted in 1,635 hits. Only studies with a natural history control group or condition were included, to ascertain that any changes in symptoms after placebo administration were placebo or nocebo effects. A placebo response was defined as the difference in the response in a condition where information was provided that effective treatment had been administered and the response in a condition where this information was not presented and symptoms were only monitored. Studies were excluded if a placebo response was defined only as the difference between a pretest and a posttest in the same

Table I Search terms used in the literature search

\begin{tabular}{|c|c|c|c|c|c|c|c|}
\hline & & And & & & And & & \\
\hline Placebo & Nocebo & & Response & Effect & & Sex & Gender \\
\hline Placebo & Nocebo & & Response & Effect & & Sex & Gender \\
\hline analgesia & hyperalgesia & & & & & & \\
\hline
\end{tabular}


group. Studies which 1) included a group or condition where placebo was administered with information that the placebo had therapeutic effects and a natural history group or condition where no treatment was provided and the symptom was only observed, or 2) administered the same amount of drug to all participants, but where different types of information about the drug were provided to different groups or conditions were included. Studies where the placebo response or the placebo effect was not the primary outcome were also included. Studies reporting significant sex differences in the placebo or the nocebo effect were included. Thus, "a larger effect," henceforth, refers to significant sex differences in the placebo or the nocebo effect.

Included studies were categorized according to design, number of participants, healthy volunteers or patients, induction method, target disorder or symptom, and outcome. The induction method was differentiated into verbal information and conditioning. Conditioning as induction method was defined as placebo or nocebo treatments induced through
1) response conditioning, for example, by surreptitiously reducing the intensity of a painful stimuli, or 2) response conditioning by social observational modeling.

\section{Statistics}

Chi-square tests were conducted to test the association between 1) placebo and nocebo effects and sex, and 2) induction method and sex.

\section{Results}

Eighteen studies satisfied the inclusion and exclusion criteria. Further details about the identification, inclusion, and exclusion process are displayed in Figure 1. References for the included studies are presented in Box S1. Eight studies investigated placebo analgesia, and two studies investigated nocebo hyperalgesia. The remaining eight studies investigated cognitive performance, mental distress, dopaminergic functioning, irritable bowel syndrome (IBS) symptoms, nausea, and reverse reactions to pharmacological treatments.

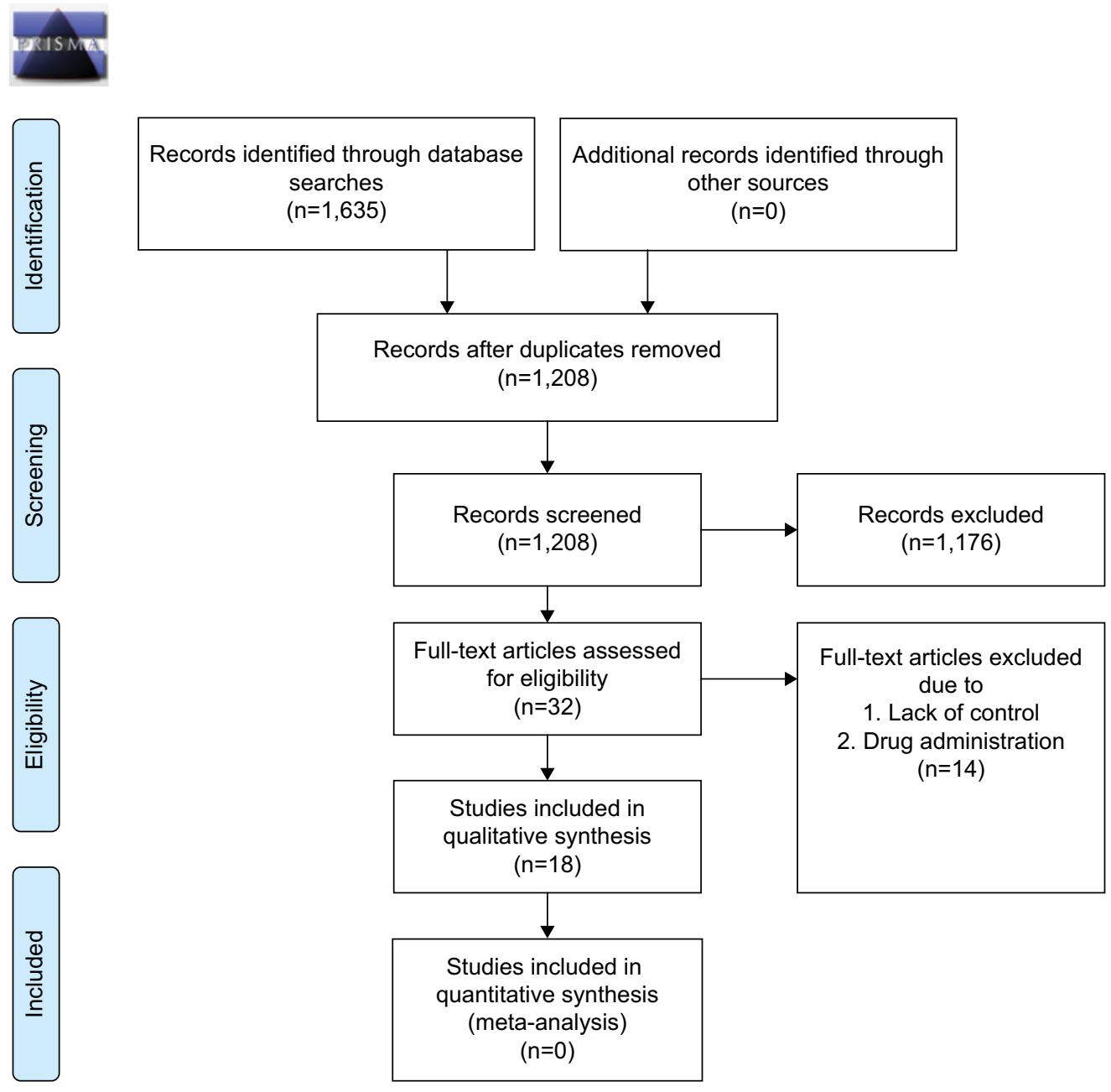

Figure I PRISMA flow diagram. 
Variables such as emotions and stress were included when they were relevant for the interpretation of the results. The studies are summarized in Table 2 and presented with full references in Appendix 1.

Among the 12 placebo studies, only males responded with a placebo effect, or with a larger placebo effect than females, in eight studies.
The association between sex and placebo and nocebo responding was significant $\left(\chi^{2}[1, N=18], p=0.046\right)$, indicating that more studies showed a placebo effect in males compared to females, and more studies showed a nocebo effect in females compared to males.

Additionally, the association between induction method and sex in placebo and nocebo responding was significant

Table 2 Included studies

\begin{tabular}{|c|c|c|c|c|c|c|}
\hline Study & Design & $\mathbf{N}$ (Females) & Sample & $\begin{array}{l}\text { Induction } \\
\text { method }\end{array}$ & $\begin{array}{l}\text { Target disorderl } \\
\text { symptom }\end{array}$ & Outcome \\
\hline $\begin{array}{l}\text { Aslaksen and } \\
\text { Lyby }^{3}\end{array}$ & Mixed design & III (76) & $\begin{array}{l}\text { Healthy } \\
\text { volunteers }\end{array}$ & $\begin{array}{l}\text { Verbal } \\
\text { information }\end{array}$ & Pain & $\begin{array}{l}\text { Significantly larger nocebo } \\
\text { hyperalgesic effect on pain report } \\
\text { in females than in males }\end{array}$ \\
\hline Aslaksen et al ${ }^{4}$ & $\begin{array}{l}\text { Within } \\
\text { subjects } \\
\text { design }\end{array}$ & $33(17)$ & $\begin{array}{l}\text { Healthy } \\
\text { volunteers }\end{array}$ & $\begin{array}{l}\text { Verbal } \\
\text { information }\end{array}$ & Pain & $\begin{array}{l}\text { Significant placebo effect on } \\
\text { pain unpleasantness and the P2 } \\
\text { component in the EEG in males, } \\
\text { but not in females }\end{array}$ \\
\hline $\begin{array}{l}\text { Bjørkedal and } \\
\text { Flaten }^{44}\end{array}$ & Mixed design & $23(7)$ & $\begin{array}{l}\text { Healthy } \\
\text { volunteers }\end{array}$ & $\begin{array}{l}\text { Verbal } \\
\text { information }\end{array}$ & Pain & $\begin{array}{l}\text { Significant placebo effect on the } \\
\text { P2 component in males, but not } \\
\text { in females }\end{array}$ \\
\hline $\begin{array}{l}\text { Aslaksen and } \\
\text { Flaten }{ }^{43}\end{array}$ & $\begin{array}{l}\text { Within } \\
\text { subjects } \\
\text { design }\end{array}$ & $63(32)$ & $\begin{array}{l}\text { Healthy } \\
\text { volunteers }\end{array}$ & $\begin{array}{l}\text { Verbal } \\
\text { information }\end{array}$ & Pain & $\begin{array}{l}\text { Significant placebo effect on pain } \\
\text { intensity in males, but not in } \\
\text { females }\end{array}$ \\
\hline Flaten et $\mathrm{al}^{48}$ & Mixed design & $84(47)$ & $\begin{array}{l}\text { Healthy } \\
\text { volunteers }\end{array}$ & $\begin{array}{l}\text { Verbal } \\
\text { information }\end{array}$ & Pain & $\begin{array}{l}\text { Significant placebo effect on pain } \\
\text { tolerance in males, but not in } \\
\text { females }\end{array}$ \\
\hline $\begin{array}{l}\text { Butcher and } \\
\text { Carmody }{ }^{5}\end{array}$ & $\begin{array}{l}\text { Within } \\
\text { subjects } \\
\text { design }\end{array}$ & $20(10)$ & $\begin{array}{l}\text { Healthy } \\
\text { volunteers }\end{array}$ & $\begin{array}{l}\text { Verbal } \\
\text { information }\end{array}$ & Pain & $\begin{array}{l}\text { Significant placebo effect on pain } \\
\text { tolerance in males, but not in } \\
\text { females }\end{array}$ \\
\hline $\begin{array}{l}\text { Krummenacher } \\
\text { et } \mathrm{a}^{52}\end{array}$ & $\begin{array}{l}\text { Between- } \\
\text { groups design }\end{array}$ & $49(23)$ & $\begin{array}{l}\text { Healthy } \\
\text { volunteers } \\
\text { (Children) }\end{array}$ & $\begin{array}{l}\text { Verbal } \\
\text { information }\end{array}$ & Pain & $\begin{array}{l}\text { Placebo effect on heat pain } \\
\text { threshold in boys and girls, but } \\
\text { larger effect in girls compared to } \\
\text { boys }\end{array}$ \\
\hline $\begin{array}{l}\text { Theysohn } \\
\text { et } \mathrm{al}^{56}\end{array}$ & $\begin{array}{l}\text { Within- } \\
\text { subjects } \\
\text { design }\end{array}$ & $30(15)$ & $\begin{array}{l}\text { Healthy } \\
\text { volunteers }\end{array}$ & $\begin{array}{l}\text { Verbal } \\
\text { information }\end{array}$ & Pain & $\begin{array}{l}\text { Placebo effect on pain report } \\
\text { in both males and females } \\
\text { Significantly larger placebo effect } \\
\text { on neural modulation in males } \\
\text { compared to females }\end{array}$ \\
\hline Colloca et $\mathrm{al}^{29}$ & $\begin{array}{l}\text { Between- } \\
\text { groups design }\end{array}$ & $109(54)$ & $\begin{array}{l}\text { Healthy } \\
\text { volunteers }\end{array}$ & $\begin{array}{l}\text { Verbal } \\
\text { information }\end{array}$ & Pain & $\begin{array}{l}\text { Placebo response enhanced } \\
\text { and cortisol levels decreased } \\
\text { significantly by vasopressin in } \\
\text { females, but not in males }\end{array}$ \\
\hline $\begin{array}{l}\text { Swider and } \\
\text { Babel }^{6}\end{array}$ & $\begin{array}{l}\text { Between- } \\
\text { groups design }\end{array}$ & $84(42)$ & $\begin{array}{l}\text { Healthy } \\
\text { volunteers }\end{array}$ & Conditioning & Pain & $\begin{array}{l}\text { Nocebo effect in males and } \\
\text { females, but significantly larger } \\
\text { nocebo effect on pain report in } \\
\text { females than in males }\end{array}$ \\
\hline Oken et $\mathrm{al}^{22}$ & $\begin{array}{l}\text { Between- } \\
\text { groups design }\end{array}$ & $40(20)$ & $\begin{array}{l}\text { Healthy } \\
\text { volunteers }\end{array}$ & $\begin{array}{l}\text { Verbal } \\
\text { information }\end{array}$ & Cognitive performance & $\begin{array}{l}\text { Significant placebo effect on } \\
\text { choice reaction time in males, but } \\
\text { not in females }\end{array}$ \\
\hline Haltia et $\mathrm{al}^{23}$ & $\begin{array}{l}\text { Within- } \\
\text { subjects } \\
\text { design }\end{array}$ & $24(12)$ & $\begin{array}{l}\text { Healthy } \\
\text { volunteers }\end{array}$ & $\begin{array}{l}\text { Verbal } \\
\text { information }\end{array}$ & Dopaminergic functioning & $\begin{array}{l}\text { Significant placebo effect on } \\
\text { reported drug effect in females, } \\
\text { but not in males }\end{array}$ \\
\hline Kelley et $\mathrm{a}^{50}$ & $\begin{array}{l}\text { Between- } \\
\text { groups design }\end{array}$ & $289(216)$ & $\begin{array}{l}\text { Patients with } \\
\text { IBS }\end{array}$ & $\begin{array}{l}\text { Verbal } \\
\text { information }\end{array}$ & IBS symptoms & $\begin{array}{l}\text { Significantly larger placebo effect } \\
\text { on IBS symptoms in females than } \\
\text { in males }\end{array}$ \\
\hline $\begin{array}{l}\text { Klosterhalfen } \\
\text { et } \mathrm{al}^{24} \text {, } \\
\text { experiment I }\end{array}$ & $\begin{array}{l}\text { Within- } \\
\text { subjects } \\
\text { design }\end{array}$ & $48(24)$ & $\begin{array}{l}\text { Healthy } \\
\text { volunteers }\end{array}$ & Conditioning & Nausea & $\begin{array}{l}\text { Significant nocebo effect on } \\
\text { rotation tolerance in females, but } \\
\text { not in males }\end{array}$ \\
\hline
\end{tabular}


Table 2 (Continued)

\begin{tabular}{|c|c|c|c|c|c|c|}
\hline Study & Design & N (Females) & Sample & $\begin{array}{l}\text { Induction } \\
\text { method }\end{array}$ & $\begin{array}{l}\text { Target disorderl } \\
\text { symptom }\end{array}$ & Outcome \\
\hline $\begin{array}{l}\text { Klosterhalfen } \\
\text { et } \mathrm{al}^{24} \text {, } \\
\text { experiment } 2\end{array}$ & $\begin{array}{l}\text { Within- } \\
\text { subjects } \\
\text { design }\end{array}$ & $48(24)$ & $\begin{array}{l}\text { Healthy } \\
\text { volunteers }\end{array}$ & $\begin{array}{l}\text { Verbal } \\
\text { information }\end{array}$ & Nausea & $\begin{array}{l}\text { Significant nocebo effect on } \\
\text { rotation tolerance in males, but } \\
\text { not in females }\end{array}$ \\
\hline Faasse et $\mathrm{al}^{47}$ & $\begin{array}{l}\text { Between- } \\
\text { groups design }\end{array}$ & $82(5 \mathrm{I})$ & $\begin{array}{l}\text { Healthy } \\
\text { volunteers }\end{array}$ & Conditioning & $\begin{array}{l}\text { Symptoms associated with } \\
\text { intake of an inert medication } \\
\text { (participants was informed } \\
\text { that the medication was a } \\
\text { beta-blocker, but in fact they } \\
\text { received a placebo). }\end{array}$ & $\begin{array}{l}\text { Significant nocebo effect on } \\
\text { total reported symptoms } \\
\text { and symptoms attributed to } \\
\text { medication in females, but not in } \\
\text { males }\end{array}$ \\
\hline Lorber et $\mathrm{al}^{53}$ & Mixed design & $86(5 \mathrm{I})$ & $\begin{array}{l}\text { Healthy } \\
\text { volunteers }\end{array}$ & Conditioning & $\begin{array}{l}\text { Symptoms associated } \\
\text { with inhalation of an } \\
\text { inert environmental toxin } \\
\text { (participants was informed } \\
\text { that the medication was a } \\
\text { suspected environmental toxin, } \\
\text { but, in fact, it was a placebo) }\end{array}$ & $\begin{array}{l}\text { Significant nocebo effect on } \\
\text { symptom report in females, but } \\
\text { not in males }\end{array}$ \\
\hline $\begin{array}{l}\text { Abrams and } \\
\text { Kushner }^{25}\end{array}$ & $\begin{array}{l}\text { Between- } \\
\text { groups design }\end{array}$ & $4 \mid(25)$ & $\begin{array}{l}\text { Participants } \\
\text { were } \\
\text { diagnosed with } \\
\text { social phobia }\end{array}$ & $\begin{array}{l}\text { Verbal } \\
\text { information }\end{array}$ & $\begin{array}{l}\text { Mental distress, fear of } \\
\text { negative evaluation }\end{array}$ & $\begin{array}{l}\text { Significant placebo effect on } \\
\text { mental distress in males only }\end{array}$ \\
\hline
\end{tabular}

Abbreviations: EEG, electroencephalogram; IBS, irritable bowel syndrome

$\left(\chi^{2}[1, N=18], p=0.023\right)$. Thus, verbal information induced placebo effects more frequently in males, whereas classical conditioning more frequently induced nocebo effects in females.

\section{Discussion}

The results showed that placebo responses were more often seen in males compared to females, whereas nocebo responses were more often observed in females than in males. Moreover, verbally induced placebo responses were more frequent in males than in females, whereas conditioned nocebo responses were more frequent in females than in males. There are several potential explanations for these sex differences. In the following text, we argue that sex differences in placebo and nocebo responding are due to sex differences in 1) affective responses to placebo and nocebo treatment, and 2) underlying psychophysiological mechanisms.

\section{Sex differences in the placebo effect}

The finding that males displayed placebo responses more frequently than females may be due to sex differences in psychophysiological mechanisms involved in stress and anxiety. Increased negative emotions may induce increased pain ${ }^{26}$ and result in nocebo responding. Activation of endogenous pain modulatory processes by stress, as in SIA, ${ }^{19}$ or by $\mathrm{DNIC}^{18}$ have been reported to reduce pain more in males than in females. Both these procedures involve increased stress. Placebo analgesia, on the other hand, is partly due to decreased stress. ${ }^{4}$ The association between reduced stress and reduced pain report in males, but not in females, after placebo administration could suggest that males are more responsive to stress-related endogenous pain modulatory processes than females. McCubbin et al showed that the effect of relaxation training was blocked by administration of naloxone, indicating that the effect of relaxation training was mediated by opioids. ${ }^{27}$ Thus, opioids are activated by both increased and decreased stress. Koepp et al used positron emission tomography and observed reduced binding of a $\mu$-receptor agonist in subjects that experienced positive emotions. ${ }^{28}$ The finding indicated that positive emotions were related to increased opioid activity. Thus, decreased stress and increased positive emotions have been associated with increased opioid activity, and this could be part of the mechanism underlying placebo analgesia. Accordingly, sex differences in this mechanism may partly explain the sex differences in placebo responding reported in this review.

The finding that vasopressin enhances the magnitude of the placebo effect and decreases stress levels in females, but not in males ${ }^{29}$ supports the hypothesis that sex differences in the placebo effect are explained by sex differences in stress and the underlying neurophysiological and neurobiological mechanisms. Vasopressin is involved in processing and regulation of social behaviors, and it has been reported that males and females respond with different brain activation and behavior after vasopressin administration. Colloca et a ${ }^{29}$ administered intranasal vasopressin as placebo treatment and 
uncovered that females with the lowest cortisol and anxiety levels responded with the largest vasopressin-induced placebo effects. This suggests that high levels of stress and negative emotions in females are central for the explanation of sex differences in the placebo effect. Kessner et al included only males in a study investigating the effect of oxytocin on placebo analgesia and reported that oxytocin increased the placebo analgesic response in males. ${ }^{30}$ As vasopressin, oxytocin is involved in regulation of social behaviors. Pharmacological interventions for investigating placebo and nocebo effects represent a novel and promising approach, also for the understanding of sex differences in placebo and nocebo effects.

\section{Sex differences in the nocebo effect}

The relationship between high levels of anxiety and high levels of pain is stronger in females than in males ${ }^{31,32}$ and may explain the observations that females respond more often and stronger to nocebo hyperalgesic treatment than males. Swider and Babel showed that social observational modeling induced larger nocebo hyperalgesic responses in females than in males and suggested that this difference was due to larger increases in anxiety in females than in males. ${ }^{6}$

Previous negative drug experiences may enhance nocebo responding. Liccardi et al investigated adverse reactions after oral administration of placebo in patients that previously had reported adverse reactions to different medications. ${ }^{33}$ It was found that adverse reactions to placebo were significantly more frequent in females compared to males. Ströhle investigated sex differences in responses to placebo and sodium lactate in patients diagnosed with panic disorder. ${ }^{34}$ Infusion of sodium lactate increases anxiety levels and may generate panic attacks in patients with panic disorder. Females diagnosed with panic disorder responded with higher anxiety to infusion of placebo, compared to males with panic disorder. However, the studies by Liccardi et $\mathrm{al}^{33}$ and Ströhle ${ }^{34}$ did not include a natural history control condition and only suggest that females display larger increases in anxiety after a nocebo has been administered, compared to males.

\section{Sex differences in the placebo and nocebo effect due to the induction method}

Klosterhalfen et al showed that females responded more strongly than males to conditioned stimuli, whereas males responded more strongly than females toward verbal suggestions. ${ }^{24}$ This hypothesis fits well with findings from the present review. Activation of the endogenous opioid system mediates placebo analgesia, and naloxone inhibits or abol- ishes placebo analgesic responses. However, naloxone does not reduce all types of placebo responses. Therefore, not all placebo responses are mediated through the endogenous opioid system. Amanzio and Benedetti reported that placebo analgesia induced by verbal information was reduced by naloxone, and that placebo analgesia induced by classical conditioning was naloxone-insensitive if the previously administered drug was non-opioid. ${ }^{35}$ This suggests that verbally induced placebo responses are mediated by the endogenous opioid system, whereas conditioned placebo responses are mediated by other mechanisms. Thus, the stronger verbally induced placebo responses in males may be due to a more effective endogenous opioid system in males, compared to females.

An alternative hypothesis for the sex differences in nocebo responses is that adverse drug reactions (nocebo responses) may be a form of compensatory conditioned response, ${ }^{36}$ but there is no evidence that these are stronger in females. ${ }^{37}$ Developing a method for measuring information processing in the context of placebo effects may be valuable for future investigations of sex differences. Knowledge of how previous experiences with medications or treatments influence the placebo effect in males and females could contribute to the understanding of the observed sex differences in placebo responding. It is suggested that future studies report previous experience with medications or treatments.

A recent meta-analysis that included randomized controlled trials on psychiatric treatment found no sex differences in the placebo arm of these trials. ${ }^{38}$ However, the included studies lacked a natural history group. Thus, as several processes other than expectations could be acting in those control groups, that meta-analysis is not relevant for the present review. Although performing a meta-analysis had been preferable in the present study, the required data were not reported in several of the included studies.

There are several limitations to this study. Five of the included studies came from the same laboratory. Two of the included studies were investigating the placebo effect in patients, whereas the remaining 16 investigated placebo or nocebo effects in healthy volunteers. Additionally, the included studies investigated placebo or nocebo effects in several different symptoms (pain, nausea, cognitive performance, mental distress, dopaminergic functioning, IBS symptoms, and side effects). Furthermore, although the placebo and nocebo effect often are defined as similar but opposing effects, producing, for example, opposite effects on pain report and brain activation, ${ }^{39}$ it cannot be precluded 
that the results from the present review are not confounded. Another limitation is the small number of included studies, which may limit the generalizability of the findings. Moreover, most studies on the placebo and nocebo effect do not report on sex differences, possibly due to a lack of examining sex differences, or absence of sex differences. Consequently, there is a potential for negative or unreported data on sex differences in placebo and nocebo effects. Thus, the findings from the present study might be biased or underpowered. It should also be noted that studies have reported that sex differences in pain reporting are due to the sex of the experimenter. However, although some journals require authors to report experimenter sex, none of the included studies in the present review investigated the contribution of the sex of the experimenter. To increase the understanding of the repeatedly observed sex differences in the placebo and the nocebo effect, it is suggested that future studies report on sex differences in the placebo and nocebo effect as well as the sex of the experimenter.

\section{Conclusion}

This study suggests that placebo responses are more often observed in males than in females, and that nocebo responses are more often observed in females than in males. Additionally, verbally induced placebo responses are observed more often in males compared to females, whereas conditioned nocebo responses are observed more often in females compared to males. The observed sex differences in placebo responding are probably due to larger stress reduction in males compared to females. The sex differences in nocebo responding may be explained by larger increases in stress and anxiety in females than in males. Furthermore, endogenous opioid transmission has been reported to be more effective in males compared to females and may, therefore, explain the observed sex differences in placebo analgesia and nocebo hyperalgesia.

\section{Acknowledgment}

The study was supported by a grant from the Bial Foundation (grant no. 186/10) and the UiT, University of Tromsø, Tromsø, Norway.

\section{Disclosure}

The authors report no conflicts of interest in this work.

\section{References}

1. Flaten MA, al'Absi M. Placebo and placebo effect. In: Gellman MD, Rick Turner J, editors. Encyclopedia of Behavioral Medicine. New York: Springer; 2013:1497-1499.
2. Benedetti F. The opposite effects of the opiate antagonist naloxone and the cholecystokinin antagonist proglumide on placebo analgesia. Pain. 1996;64(3):535-543.

3. Aslaksen PM, Lyby PS. Fear of pain potentiates nocebo hyperalgesia. J Pain Res. 2015;8:703-710.

4. Aslaksen PM, Bystad M, Vambheim SM, Flaten MA. Gender differences in placebo analgesia: event-related potentials and emotional modulation. Psychosom Med. 2011;73(2):193-199.

5. Butcher BE, Carmody JJ. Sex differences in analgesic response to ibuprofen are influenced by expectancy: a randomized, crossover, balanced placebo-designed study. Eur J Pain. 2012;16(7):1005-1013.

6. Swider K, Babel P. The effect of the sex of a model on nocebo hyperalgesia induced by social observational learning. Pain. 2013;154(8): 1312-1317.

7. Riley JL 3rd, Robinson ME, Wise EA, Myers CD, Fillingim RB. Sex differences in the perception of noxious experimental stimuli: a metaanalysis. Pain. 1998;74(2-3):181-187.

8. Garcia E, Godoy-Izquierdo D, Godoy JF, Perez M, Lopez-Chicheri I. Gender differences in pressure pain threshold in a repeated measures assessment. Psychol Health Med. 2007;12(5):567-579.

9. Woodrow KM, Friedman GD, Siegelaub AB, Collen MF. Pain tolerance: differences according to age, sex and race. Psychosom Med. 1972;34(6):548-556.

10. Fillingim RB, King CD, Ribeiro-Dasilva MC, Rahim-Williams B, Riley JL 3rd. Sex, gender, and pain: a review of recent clinical and experimental findings. J Pain. 2009;10(5):447-485.

11. Forgays DG, Rzewnicki R, Ober AJ, Forgays DK. Headache in college students: a comparison of four populations. Headache. 1993;33(4):182-190.

12. Rollman GB, Lautenbacher S. Sex differences in musculoskeletal pain. Clin J Pain. 2001;17(1):20-24.

13. Yunus MB. A comprehensive medical evaluation of patients with fibromyalgia syndrome. Rheum Dis Clin North Am. 2002;28(2):201-217.

14. Eippert F, Bingel U, Schoell ED, et al. Activation of the opioidergic descending pain control system underlies placebo analgesia. Neuron. 2009;63(4):533-543.

15. Benedetti F, Amanzio M, Casadio C, Oliaro A, Maggi G. Blockade of nocebo hyperalgesia by the cholecystokinin antagonist proglumide. Pain. 1997;71(2):135-140.

16. Benedetti F, Amanzio M. Mechanisms of the placebo response. Pulm Pharmacol Ther. 2013;26(5):520-523.

17. Benedetti F, Amanzio M, Vighetti S, Asteggiano G. The biochemical and neuroendocrine bases of the hyperalgesic nocebo effect. $J$ Neurosci. 2006;26(46):12014-12022.

18. Popescu A, LeResche L, Truelove EL, Drangsholt MT. Gender differences in pain modulation by diffuse noxious inhibitory controls: a systematic review. Pain. 2010;150(2):309-318.

19. Butler RK, Finn DP. Stress-induced analgesia. Prog Neurobiol. 2009;88(3):184-202.

20. Sternberg WF, Liebeskind JC. The analgesic response to stress: genetic and gender considerations. Eur J Anaesthesiol Suppl. 1995;10:14-17.

21. Mogil JS, Sternberg WF, Kest B, Marek P, Liebeskind JC. Sex differences in the antagonism of swim stress-induced analgesia: effects of gonadectomy and estrogen replacement. Pain. 1993;53(1): $17-25$.

22. Oken BS, Flegal K, Zajdel D, Kishiyama S, Haas M, Peters D. Expectancy effect: impact of pill administration on cognitive performance in healthy seniors. J Clin Exp Neuropsychol. 2008;30(1):7-17.

23. Haltia LT, Rinne JO, Helin S, Parkkola R, Någren K, Kaasinen V. Effects of intravenous placebo with glucose expectation on human basal ganglia dopaminergic function. Synapse. 2008;62(9):682-688.

24. Klosterhalfen S, Kellermann S, Braun S, et al. Gender and the nocebo response following conditioning and expectancy. J Psychosom Res. 2009;66(4):323-328.

25. Abrams K, Kushner MG. The moderating effects of tension-reduction alcohol outcome expectancies on placebo responding in individuals with social phobia. Addict Behav. 2004;29(6):1221-1224. 
26. Lyby PS, Aslaksen PM, Flaten MA. Is fear of pain related to placebo analgesia? J Psychosom Res. 2010;68(4):369-377.

27. McCubbin JA, Wilson JF, Bruehl S, et al. Relaxation training and opioid inhibition of blood pressure response to stress. J Consult Clin Psychol. 1996;64(3):593-601.

28. Koepp MJ, Hammers A, Lawrence AD, Asselin MC, Grasby PM, Bench CJ. Evidence for endogenous opioid release in the amygdala during positive emotion. Neuroimage. 2009;44(1):252-256.

29. Colloca L, Pine DS, Ernst M, Miller FG, Grillon C. Vasopressin boosts placebo analgesic effects in women: a randomized trial. Biol Psychiatry. 2016;79(10):794-802.

30. Kessner S, Sprenger C, Wrobel N, Wiech K, Bingel U. Effect of oxytocin on placebo analgesia: a randomized study. JAMA. 2013;310(16): 1733-1735.

31. Goffaux P, Michaud K, Gaudreau J, Chalaye P, Rainville P, Marchand $\mathrm{S}$. Sex differences in perceived pain are affected by an anxious brain. Pain. 2011;152(9):2065-2073.

32. Keogh E, Birkby J. The effect of anxiety sensitivity and gender on the experience of pain. Cogn Emot. 1999;13(6):813-829.
33. Liccardi G, Senna G, Russo M. Evaluation of the nocebo effect during oral challenge in patients with adverse drug reactions. J Investig Allergol Clin Immunol. 2004;14(2):104-107.

34. Ströhle A. Increased response to a putative panicogenic nocebo administration in female patients with panic disorder. J Psychiatr Res. 2000;34(6):439-442.

35. Amanzio M, Benedetti F. Neuropharmacological dissection of placebo analgesia: expectation-activated opioid systems versus conditioningactivated specific subsystems. J Neurosci. 1999;19(1):484-494.

36. Siegel S. Drug tolerance, drug addiction, and drug anticipation. Curr Dir Psychol Sci. 2005;14(6):296-300.

37. Flaten MA, Simonsen T, Waterloo K, Olsen H. Pharmacological classical conditioning in humans. Hum Psychopharmacol Clin Exp. 1997;12(4):369-377.

38. Weimer K, Colloca L, Enck P. Placebo effects in psychiatry: mediators and moderators. Lancet Psychiatry. 2015;2(3):246-257.

39. Benedetti F, Lanotte M, Lopiano L, Colloca L. When words are painful: unraveling the mechanisms of the nocebo effect. Neuroscience. 2007;147(2):260-271.
Journal of Pain Research

\section{Publish your work in this journal}

The Journal of Pain Research is an international, peer reviewed, open access, online journal that welcomes laboratory and clinical findings in the fields of pain research and the prevention and management of pain. Original research, reviews, symposium reports, hypothesis formation and commentaries are all considered for publication.

\section{Dovepress}

The manuscript management system is completely online and includes a very quick and fair peer-review system, which is all easy to use. Visit http://www.dovepress.com/testimonials.php to read real quotes from published authors. 


\section{Supplementary materials}

\section{Box SI Reference list of the included studies}

Abrams, K. \& Kushner, M.G. (2004). The moderating effects of tension-reduction alcohol

outcome expectancies on placebo responding in individuals with social phobia. Addictive Behaviors, 29:1221-1224.

Aslaksen, P.M. \& Lyby, P.S. (2015). Fear of pain potentiates nocebo hyperalgesia. Journal of

Pain Research, 8:703-710

Aslaksen, P.M., Bystad, M., Vambheim, S.M. \& Flaten, M.A. (2011). Gender differences in placebo analgesia: event-related potentials and emotional modulation. Psychosomatic Medicine, 73:193-199.

Aslaksen, P.M. \& Flaten, M.A. (2008). The roles of physiological and subjective stress in the effectiveness of a placebo on experimentally induced pain. Psychosomatic Medicine, 70:811-818.

Bjørkedal, E. \& Flaten, M.A. (2011). Interaction between expectancies and drug effects: an experimental investigation of placebo analgesia with caffeine as an active placebo. Psychopharmacology, 215:2233-4.

Butcher, B.E. \& Carmody, J.J. (2012). Sex differences in analgesic response to ibuprophen are influenced by expectancy: a randomized, crossover, balanced placebo-designed study. European Journal of Pain, 16(7):1005-13.

Colloca, L., Pine, D.S., Ernst, M., Miller, F.G. \& Grillon, C. (2016). Vasopressin Bossts

Placebo Analgesic Effects in Women: A Randomized Trial. Biological Psychiatry;79(10):794-802.

Faasse, K., Grey, A., Jordan, R., Garland, S. \& Petrie, K.J. (2015). Seeing is believing: Impact of social modeling on placebo and nocebo responding. Health Psychology;34(8):880-5.

Flaten, M.A., Aslaksen, P.M., Finset, A, Simonsen, T. \& Johansen, O. (2006). Cognitive and emotional factors in placebo analgesia. Journal of Psychosomatic Research;61:81-89.

Haltia, L.T., Rinne, J.O., Helin, S., Parkkola, R., Någren, K. \& Kaasinen, V. (2008). Effects of intravenous placebo with glucose expectation on human basal ganglia dopaminergic function. Synapse;62(9):682-8.

Kelley, J.M., Lembo, A.J., Ablon, J.S., Villanueva, J.J., Conboy, L.A., Levy, R., Marci, C.D.,

Kerr, C.E., Kirsch, I., Jacobson, E.E., Riess, H. \& Kaptchuk, T.J. (2009). Patient and practitioner influences on the placebo effect in irritable bowel syndrome. Psychosomatic Medicine;71(7):789-97.

Klosterhalfen, S., Kellermann, S., Braun, S., Kowalski, A., Schrauth, M., Zipfel, S. \& Enck, P. (2009). Gender and the nocebo response following conditioning and expectancy. Journal of Psychosomatic Research;66(4):323-8.

Krummenacher, P., Kossowsky, J., Schwarz, C., Brugger, P., Kelley, J.M., Meyer, A. \& Gaab, J. (2014). Expectancy-induced placebo analgesia in children and the role of magical thinking. Journal of Pain, 15(12):1282-93.

Lorber, W., Mazzoni, G. \& Kirsch, I. (2007). Illness by suggestion: expectancy, modeling, and gender in the production of psychosomatic symptoms. Ann Behav Med, 33(1):112-6.

Oken, B.S., Flegal, K., Zajdel, D., Kishiyama, S., Haas, M. \& Peters, D. (2008). Expectancy effect: Impact of pill administration on cognitive performance in healthy seniors. Journal of Clinical and Experimental Neuropsychology, 30:7-17.

Swider, K. \& Babel, P. (2013). The effect of the sex of a model on nocebo hyperalgesia induced by social observational learning. Pain, 154(8):1312-7.

Theysohn, N., Schmid, J., Icenhour, A., Mewes, C., Forsting, M., Gizewski, E.R., Schedlowski, M., Eisenbruch, S. \& Benson, S. (2014). Are there sex differences in placebo analgesia during visceral pain processing? A fMRI study in healthy subjects. Neurogastroenterol Motil., 26(12):1743-53.

Journal of Pain Research

\section{Publish your work in this journal}

The Journal of Pain Research is an international, peer reviewed, open access, online journal that welcomes laboratory and clinical findings in the fields of pain research and the prevention and management of pain. Original research, reviews, symposium reports, hypothesis formation and commentaries are all considered for publication.

\section{Dovepress}

The manuscript management system is completely online and includes a very quick and fair peer-review system, which is all easy to use. Visit http://www.dovepress.com/testimonials.php to read real quotes from published authors. 